\title{
FIRST CONFIRMED RECORD OF THE BLUE TANG, ACANTHURUS COERULEUS (ACTINOPTERYGII: PERCIFORMES: ACANTHURIDAE) IN THE MEDITERRANEAN
}

\author{
Daniel GOLANI ${ }^{*}$, Grigori ASKAROV², and Brenda APPELBAUM-GOLANI ${ }^{3}$ \\ ${ }^{1}$ Department of Ecology, Evolution and Behavior and The National Natural History Collections of the Hebrew Uni- \\ versity, The Hebrew University of Jerusalem, Jerusalem, Israel \\ ${ }^{2}$ School of Marine Sciences, Ruppin Academic Center, Michmoret, Israel \\ ${ }^{3}$ Mt. Scopus Library, The Hebrew University of Jerusalem, Jerusalem, Israel
}

Golani D., Askarov G., Appelbaum-Golani B. 2015. First confirmed record of the blue tang, Acanthurus coeruleus (Actinopterygii: Perciformes: Acanthuridae) in the Mediterranean. Acta Ichthyol. Piscat. 45 (3): 311-313.

\begin{abstract}
A single specimen of a sub-adult specimen of the Atlantic species, Acanthurus coeruleus Bloch et Schneider, 1801, was collected in the Mediterranean coast of Israel. This collection was the first confirmed record of this species in the Mediterranean since hitherto it was known from this region only by a single underwater photograph from Cyprus. We postulate that this species may be considered as having established a population in this region.
\end{abstract}

Keywords: fish, exotic, Israel, fish, population establishment

On 20 November 2014 a sub-adult specimen of a blue tang, Acanthurus coeruleus Bloch et Schneider, 1801, of $120 \mathrm{~mm} \mathrm{SL} \mathrm{(161} \mathrm{mm} \mathrm{TL),} \mathrm{weighing} 98.0 \mathrm{~g}$ (Fig. 1), was speared at a depth of $11 \mathrm{~m}$ over rocky habitat in the vicinity of Haifa Bay, Israel. This collection was the first confirmed record of this species in the Mediterranean. Hitherto it was known from this region only by an underwater photograph from Cyprus (Langeneck et al. 2012). The specimen was deposited in the Fish Collection of the National Natural Collections of the Hebrew University of Jerusalem and received the catalogue number HUJ 20363.

\section{ACANTHURIDAE}

Acanthurus coeruleus Bloch et Schneider, 1801

Description of the Mediterranean specimen. Very deep body (1.47 times in SL) and very compressed. Small head (3.60 times in SL); Eye located high on head (3.47), interorbital distance greater than eye diameter (2.80) and large snout (1.16) (all times in head length). Small mouth, not reaching back past anterior vertical of eye. Pronounced lips. Series of close-set teeth, each with 3-5 denticulate edges. Sharp horizontal lancet-like spine on side of caudal peduncle, its length 4.44 times in head length. Small ctenoid scales covering entire body, extending to head reaching mouth. Scales are present also on lower part of dorsal and anal fins membrane. Continuous dorsal fin with nine spines and 25 rays. Anal fin with three spines and 23 rays (Last dorsal and anal fins rays which are divided almost to the base were counted as a single ray). Caudal fin emarginated. Pectoral fin located just behind operculum with 16 rays, upper ray much longer than lower ray. Pelvic fin with single spine and five rays, first ray being longest. Flank and belly yellowish-brown with numerous beige longitudinal lines. Back brown to dark grey. Fins yellow with thin bluish-grey margin of dorsal and anal fins. Eye surrounded by yellow ring.

Measurements, counts and colour pattern agree with Böhlke and Chaplin (1968) and Randall $(1968,2002)$, regarding the sub-adult of Acanthurus coeruleus.

Remarks. The juveniles of Acanthurus coeruleus are bright yellow as shown by Langeneck et al. (2012) from Cyprus. The adults are bluish-grey to purple. The age and size of the colour change is quite variable (Benjamin Victor, personal communication).

Acanthurus coeruleus inhabits shallow waters near coral or rocky habitats. It feeds on algae and sea grass. Its original distribution is the Western Atlantic Ocean from New York to Florida in the US to Bermuda, the Gulf of Mexico and Brazil. This species is also reported from Ascension Island in the mid-Atlantic Ocean. (Randall 2002) Acanthurus coeruleus is the second Atlantic surgeonfish to be found in the Mediterranean. It was preceded by Acanthurus monroviae Steindachner, 1876, reported 


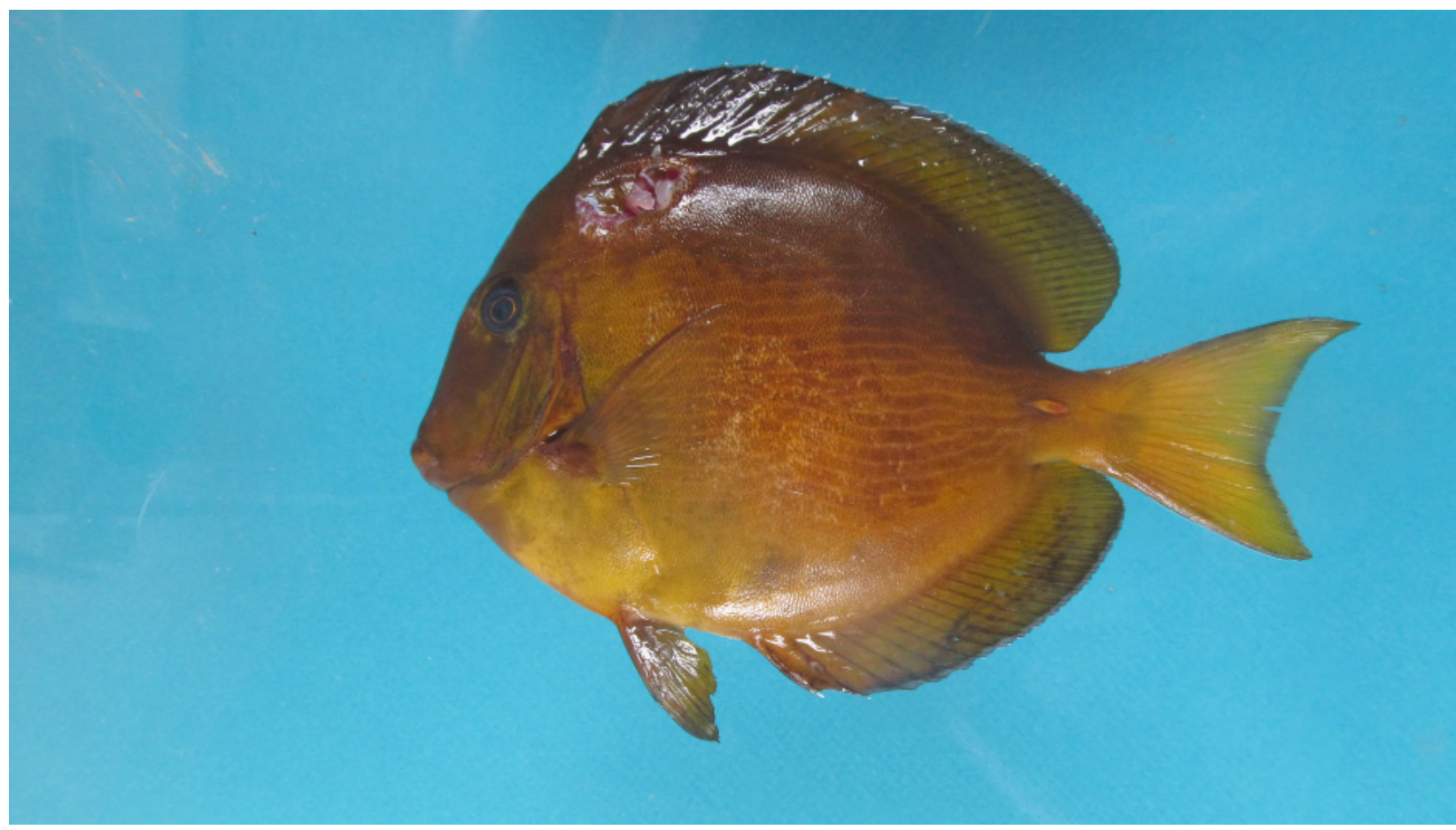

Fig. 1. Blue tang, Acanthurus coeruleus, 120 mm SL, Haifa, 20 November 2014, HUJ 20363; Photograph: D. Golani

from Israel (Golani and Sonin 1996) and from Algeria (Hemida et al. 2004).

Acanthurus coeruleus was reported for the first time in the Mediterranean based on an underwater photograph and observation from Cyprus. Therefore, the presently reported record constitutes the first confirmed record that can be studied and can substantiate the occurrence of this species in the Mediterranean. Langeneck et al. (2012) raised three possible ways for introduction of this species into the Mediterranean, namely, via ballast waters, aquarium escapee, and "natural" introduction via the Straits of Gibraltar with no relation to human activity. Although $A$. coeruleus is found in the aquarium trade, the occurrence of specimens in the Mediterranean in such long distances of ca. $400 \mathrm{~km}$ from each other suggests that the introduction of this species is another case of tropical Atlantic fish species such as Carlarius parkii (Günther, 1864) [originally reported as Arius parkii (see Marceniuk and Menezes, 2007)], Enchelycore anatina (Lowe, 1838), Cephalopholis taeniops (Valenciennes in Cuvier and Valenciennes, 1828), Pagellus bellottii Steindachner, 1882, Acanthurus monroviae Steindachner, 1876, and Solea senegalensis Kaup, 1858 (see Golani and Sonin 1996, Golani et al. 2013, Fricke et al. 2014). All these Atlantic species (except C. parkii,) were recorded in the eastern Mediterranean by more than one specimen and therefore can be considered as having established a population in this region. This phenomenon can be explained as thermophilic tropical species that found a suitable temperature regime in the Levant, as opposed to the colder regime in the western and central Mediterranean where establishing a population is more difficult.

\section{REFERENCES}

Böhlke J.E., Chaplin C.C.G. 1968. Fishes of the Bahamas and adjacent tropical waters. Livingston Publishing Company, Wynnewood, PA, USA.

Golani D., Fricke R., Appelbaum-Golani B. 2013. First record of the Senegalese sole, Solea senegalensis Kaup, 1858 (Actinopterygii: Pleuronectiformes: Soleidae) from the Mediterranean coast of Israel. Acta Ichthyologica et Piscatoria 43 (3): 319-321.

DOI: $10.3750 / A I P 2013.43 .4 .10$

Golani D., Sonin O. 1996. The occurrence of the tropical west African marine fishes Acanthurus monroviae (Acanthuridae) and Arius parkii (Ariidae) in the Levant. Aqua 2 (1): 1-3.

Fricke R., Golani D., Sonin O., Appelbaum-Golani B. 2014. First record of the red pandora, Pagellus bellottii from Israel, south-eastern Mediterranean (Teleostei: Sparidae). Marine Biodiversity Records 7: e130. DOI: $10.1017 /$ S1755267214001316

Hemida F., Diatta Y., Golani D., Ben Souissi J., Guélorget O., Capapé C. 2004. On the occurrence of the Monrovian surgeonfish, Acanthurus monroviae Steindachner, 1876 (Osteichthyes: Acanthuridae) off the coast of Algeria (southern Mediterranean). Acta Adriatica 45 (2): 181-185.

Langeneck J., Marcelli M., Simak H.C. 2012. Unexpected alien species in Cyprus waters: Acanthurus coeruleus (Actinoptererygii: Acanthuridae). Marine Biodiversity Records 5: e116.

DOI: $10.1017 / \mathrm{S} 1755267212001042$

Marceniuk A.P., Menezes N.A. 2007. Systematics of the family Ariidae (Ostariophysi, Siluriformes), with a redefinition of the genera. Zootaxa 1416: 1-126. 
Randall J.E. 1968. Caribbean reef fishes. TFH Publications, Neptune City, NJ, USA.

Randall J.E. 2002. Acanthuridae. Surgeonfishes. Pp. 1801-1805. In: Carpenter K.E. (ed.) The living resources of the Western Central Atlantic. Vol. 3. Part 2. (Opistognathidae to Molidae), sea turtles and marine mammals. FAO Species Identification Guide for Fishery Purposes and The American Society of Ichthyologists and Herpetologists, Special publication No. 5, FAO, Rome.
Received: 19 December 2014

Accepted: 2 March 2015

Published electronically: 30 September 2015 